Aus dieser Glia-dysplasie oder Glia-malformation entwicklt sich durch diffuse Gliomatose der Gliom (Benedekt u.a.). Nach Stein u.a. ist eine Pluriopotenz der Neurozyten anzunehmen, die in Richtug auf gliöse, ganglionäre, Schwannsche oder chromaffine Zellen zielen Kann. Aus diesen Gründen scheint die kombination von 3 Tumoren uns nicht zufällig zu sein.

\title{
46. Experience of an Epipharinx Tumor in which Disturbunce of Cranial Nerves were Initial and Main Symptoms
}

\author{
Toyoaki Chiba, Kazushi Shimizu \\ Department of Neurosurgery. Self Defense Forces Sapporo Hospital
}

\section{A Case of Colloid Cyst in Third Ventricle}

\author{
Shusaku Fujino, Hiroshi FukaI, Akimasa Umeda, \\ and Sadao Nakajo \\ Department of Neurosurgery, Kawasaki Medical College, Okayama
}

We have reported a case of successful removal of a colloid cyst in third ventricle. This 31-year-old male was admitted to hospital on May 29 to August 18, 1971, because of suddenly increased intracranial pressure with unconsciousness. Pneumoencephalography showed a $2.5 \mathrm{~cm}$ in diameter rounded tumor-shadow in the anterior-superior part of the third ventricle. Adding the right-sided frontal craniotomy, we have done successful subtotal removal of cystic wall. Postoperative clinicopathological diagnosis revealed a colloid cyst with ependymal-like wall. Postoperative recovery was uneventful. Statistically colloid cyst in the third ventricle (Monro cyst) is comparatively rare; choroidal cyst (including Monro cyst) represents about one per-cent of all intracranial neoplasma verified by autopsy in Japan (Ueki, Katsura 1959) and $0.3 \%$ in the world (Gruder 1935).

\section{Note on Antibiotic Therapy in Craniotomy}

Mitsumasa Kano, Haruyuki Ota and Shintaro Mori

Department of Neurosurgery Osaka Rosai Hospital, 